\title{
Phytochemical Screening and in vitro Antioxidant Activity of Hydro-Ethanolic Extract of Blighia sapida Stem Bark
}

\author{
Philip O. Amira ${ }^{1,2} \quad$ Adebayo S. Daramola ${ }^{2 *}$ Waheed A. Oyelade ${ }^{2}$ \\ 1.Department of Biochemistry, University of Ilorin, Ilorin, Nigeria \\ 2.Department of Science Technology, The Federal Polytechnic, P.M.B. 5351, Ado-Ekiti, Nigeria
}

\begin{abstract}
Blighia sapida is a plant belonging to the family of Sapindaceae. In this study we aimed to carry out the phytochemical screening of hydro-ethanolic (15\%) extract of Blighia sapida stem bark and evaluate its in vitro antioxidant activity. It was found that the hydro-ethanolic extract of Blighia sapida stem bark showed the presence of saponin, flavonoid, alkaloid, phenols and ascorbic acid. It also contains trace elements zinc and selenium. Furthermore it showed some scavenging activity but not as such could be compared with the various standards used except for nitric oxide scavenging activity.
\end{abstract}

Keywords: Blighia sapida, phytochemicals, antioxidant, trace elements

DOI: $10.7176 / \mathrm{JBAH} / 9-16-04$

Publication date: August $31^{\text {st }} 2019$

\section{Introduction}

Phytochemicals are naturally occurring in the medicinal plants, leaves, vegetables and roots that have defense mechanism and protect from various diseases. In fact, phytochemicals (or antioxidants) such as phenolic compounds (tocopherols, flavonoids and phenolic acids), nitrogen compounds (alkaloids, chlorophyll derivatives, amino acids and amines), carotenoids and ascorbic acid (Larson 1988; Hall \& Cuppett 1997) compounds inhibit, or delay the oxidation of other molecules by inhibiting the initiation or propagation of oxidizing chain reaction.

Blighia sapida is a plant belonging to the family of Sapindaceae. It is native to Western Tropical Africa and was introduced into Jamaica in the late $18^{\text {th }}$ century. It has spread to other parts of tropical America but it is still more widely known in Jamaica than elsewhere. It is commonly known as ackee. In Nigeria, it is called Gwanja Kusa (Hausa), Isin (Yoruba) and Okpu (Igbo). The fruit is known to contain saponins, which are hemolytic (Aderinola et ai. 2007). Most of the earlier studies on Blighia sapida have been on the nutritional qualities of the root (Abolaji et al. 2007) and the leaves as a dry season feed resource for West African dwarf goats in the Northern savanna zone of Nigeria (Aderinola et al. 2007) and mice (Gardiner et al. 1996). More recently, the physicochemical properties of the oil from the fruit of the species and toxicological evaluation of the oil - based diet in Wister rats have been investigated (Oladiji et al. 2009).

Tree bark is an important component of African traditional medicine as herbal medicine is still the main source of health care for the majority of Africans and in particular, Nigeria, The high cost, availability, uncertainty of use during pregnancy and undesirable side effects of synthetic drugs or drugs from other animal sources are some of the factors leading to a strong preference for drugs of plants origin.

This study is thus aimed at investigating the phytochemicals and in vitro antioxidant activity of the readily available Blighia sapida stem bark.

\section{Materials and Methods}

2.1 Chemicals: All chemicals used were of analytical grade and items are products of BDH and Sigma Chemical Ltd., UK and Accu-chek ${ }^{\circledR}$ Advantage, Roche Diagnostic, Germany.

2.2 Sourcing for the Tree Bark of Blighia sapida: A sizeable quantity of the tree bark of Blighia sapida was obtained from the compound of the Federal Polytechnic, Ado Ekiti, Nigeria.

2.3 Identification of Plant: The fruits and leaves of Blighia sapida plant were obtained from the compound of the Federal polytechnic, Ado Ekiti, Ekiti State, Nigeria and were used for the purpose of authentication of the identity of the plant at the Herbarium unit of the Department of Plant Biology, University of Ilorin, Ilorin, Nigeria. The voucher number of identification is UIH624.

2.4 Processing of sample and preparation of extract: The sample obtained was air-dried at room temperature for fifty-six (56) days until a constant weight was obtained. The air-dried tree bark of Blighia sapida was pulverized. $100 \mathrm{~g}$ of the pulverized sample was extracted with $800 \mathrm{ml}$ of $15 \%$ ethanol (hydro-ethanol) solution for seventy-two (72) hours in an extractor. The hydro-ethanolic extract was obtained by filtering with Whatman filter paper and subsequently freeze-dried in Armfield freeze-drier.

2.5.Qualitativ.e Phytochemical Analysis

Chemical tests were carried out on the hydro-ethanolic extract using modified standard procedures to identify the constituents as described by Sofowora (1993), Trease \& Evans (1989) and Harborne (1973). 


\subsection{Quantitative Determination of Phytochemicals}

2.6.1. Determination of Tannin: The tannin content of the extract was determined by using the modified procedure of Makkar (1994).

2.6.2. Determination of Saponin: The method used was that described by Obadoni \& Ochuko (2001).

2.6.3. Determination of Flavonoid: The method of Boham \& Kocipal-Abyazam (1994) was used.

2.6.4. Determination of Alkaloid: The total alkaloid content of the extract was determined using the method described by Harborne (1973).

2.6.5 Determination of Total Phenols: The total phenolic content was determined using the method described by Singleton \& Rossi (1965) using Folin-Ciocalteu's phenol reagent.

2.6.6 Determination of Zinc and Selenium: The level of zinc and selenium were determined by the method described by AOAC (2006).

\subsection{In vitro Antioxidant Assay}

2.7.1 DPPH free radical scavenging assay: The hydrogen or radical scavenging properties of the extract was determined using the stable radical DPPH (2, 2-Diphenyl-1-picrylhydrazyl hydrate) according to the method proposed and described by Blois (1958).

2.7.2. Hydroxyl radical scavenging assay: Deoxyribose assay was used to determine the hydroxyl radical scavenging activity in an aqueous medium (Halliwell et al. 1981).

2.7.3. Hydrogen peroxide decomposition assay: This activity was determined according to a method described by Long et al. (1999).

2.7.4. Nitric oxide (NO) scavenging assay: At physiological $\mathrm{pH}$, nitric oxide generated from aqueous sodium nitroprusside (SNP) solution interacts with oxygen to produce nitrite ions, which may be quantified by the Griess Illosvoy reaction (Garratt 1964).

2.7.5. Ferric reducing antioxidant assay (FRAP): The FRAP assay uses antioxidants as reductants in a redoxlinked colorimetric method with absorbance measured with a spectrophotometer (Benzie \& Strain 1999).

2.7.6. Determination of total antioxidant capacity: The total antioxidant capacity was determined in accordance with the method described by Prieto et al. (1999).

2.8 Statistical Analysis: Data were expressed as mean \pm S.E.M. of five replicates.

\subsection{Results}

3.1 Phytochemical screening of extract

The result of phytochemical screening of hydro-ethanolic extract of Blighia sapida stem bark shows the presence of saponin, flavonoid, alkaloid, phenols and ascorbic acid. It also shows the presence of the trace elements zinc and selenium (Tables 1 and 2).

Table 1: Qualitative analysis of the phytochemicals of the hydro-ethanolic extract of Blighia sapida stem bark

\begin{tabular}{|l|l|l|l|l|l|l|l|l|}
\hline Species & Extract Type & TNN & SPN & FLV & STR & TPN & AKD & PHN \\
\hline Blighia sapida & Hydro-ethanolic & - & + & + & + & + & + & + \\
\hline
\end{tabular}

Table 2: Concentrations of tannin, saponin, flavonoid, alkaloid, phenols, ascorbic acid, zinc and selenium in hydro- ethanolic extract of Blighia sapida tree bark.

\begin{tabular}{|l|l|l|l|l|l|l|l|l|l|}
\hline Species & $\begin{array}{l}\text { Extract } \\
\text { type }\end{array}$ & $\begin{array}{l}\text { Tannin } \\
(\mathbf{\%})\end{array}$ & $\begin{array}{l}\text { Saponin } \\
\mathbf{( \% )}\end{array}$ & $\begin{array}{l}\text { Flavonoid } \\
\mathbf{( \% )}\end{array}$ & $\begin{array}{l}\text { Alkaloid } \\
(\mathbf{\%})\end{array}$ & $\begin{array}{l}\text { Phenols } \\
\mathbf{( \% )}\end{array}$ & $\begin{array}{l}\text { Ascorbic } \\
\text { Acid } \\
(\mathbf{m g} / \mathbf{1 0 0 g})\end{array}$ & $\begin{array}{l}\text { Zinc } \\
(\mathbf{p p m})\end{array}$ & $\begin{array}{l}\text { Selenium } \\
(\mathbf{p p m})\end{array}$ \\
\hline $\begin{array}{l}\text { Blighia } \\
\text { sapida }\end{array}$ & $\begin{array}{l}\text { Hydro- } \\
\text { ethanolic }\end{array}$ & 0.00 & 18.30 & $\begin{array}{l}16.70 \\
\pm 0.02\end{array}$ & $\begin{array}{l}21.70 \\
\pm 3.60\end{array}$ & $\begin{array}{l}9.87 \\
\pm 0.98\end{array}$ & $\begin{array}{l}21.30 \\
\pm 4.25\end{array}$ & 16.10 & $<1.0$ \\
\hline
\end{tabular}

Values are mean \pm S.E.M of five replications of the tested extract.

\subsection{In vitro antioxidant activity}

In vitro antioxidant studies revealed that hydro-ethanolic extract of Blighia sapida stem bark showed some scavenging activity by total antioxidant capacity (TAC) with the $\mathrm{IC}_{50}$ value of $18.80 \pm 0.89 \mu \mathrm{g} / \mathrm{ml}$, ferric reducing antioxidant property with the $\mathrm{IC}_{50}$ value of $7.03 \pm 0.38 \mu \mathrm{g} / \mathrm{ml}$, DPPH radical scavenging activity with the $\mathrm{IC}_{50}$ value of $2,059.00 \pm 107.86 \mu \mathrm{g} / \mathrm{ml}$, total phenol of $9.87 \pm 0.98 \mu \mathrm{g} / \mathrm{ml}$ GAE, hydrogen peroxide radical decomposition activity with the $\mathrm{IC}_{50}$ value of $6,683 \pm 791.80 \mu \mathrm{g} / \mathrm{ml}$, hydroxyl radical scavenging activity with $\mathrm{IC}_{50}$ value of $5,971.00 \pm 938.80 \mu \mathrm{g} / \mathrm{ml}$ and nitric oxide scavenging activity with $\mathrm{IC}_{50}$ value of $482.37 \pm 20.60 \mu \mathrm{g} / \mathrm{ml}$. However, apart from the nitric oxide scavenging activity value that compares with that of the standard (i.e. ascorbic acid), all other values are a lot higher than those of the standards used (Table 3 ). 
Table 3: In vitro antioxidant activity of Blighia sapida stem bark hydro-ethanolic extract

\begin{tabular}{|c|c|c|c|c|c|c|c|}
\hline & \multicolumn{7}{|c|}{ Parameters } \\
\hline $\begin{array}{l}\text { Extract } \\
\text { Type }\end{array}$ & $\begin{array}{l}\text { Total } \\
\text { Antioxidant } \\
\text { Capacity } \\
\text { (TAC) }\end{array}$ & $\begin{array}{l}\text { Ferric } \\
\text { reducing } \\
\text { antioxidant } \\
\text { (FRAP) }\end{array}$ & $\begin{array}{l}\text { DPPH free } \\
\text { radical } \\
\text { scavenging }\end{array}$ & $\begin{array}{l}\text { Total } \\
\text { Phenol } \\
\text { (GAE) }\end{array}$ & $\begin{array}{l}\text { Hydrogen } \\
\text { Peroxide }\end{array}$ & $\begin{array}{l}\text { Hydroxyl } \\
\text { radical }\end{array}$ & $\begin{array}{l}\text { Nitric } \\
\text { oxide }\end{array}$ \\
\hline \multicolumn{8}{|c|}{ IC $_{50}$ Values $(\mu \mathrm{g} / \mathrm{ml})$} \\
\hline Hydro-thanolic & $\begin{array}{l}18.80 \\
\pm 0.89\end{array}$ & $\begin{array}{c}7.03 \\
\pm 0.38\end{array}$ & $\begin{array}{l}2059.00 \\
\pm 107.86\end{array}$ & $\begin{array}{c}9.87 \\
\pm 0.98\end{array}$ & $\begin{array}{r}6683.00 \\
\pm 791.80\end{array}$ & $\begin{array}{c}5971.00 \\
\pm 938.80\end{array}$ & $\begin{array}{c}482.37 \\
\pm \\
20.60\end{array}$ \\
\hline \multicolumn{8}{|c|}{ Standards } \\
\hline Ascorbic acid & - & - & $\begin{array}{r}69.19 \\
\pm 5.02\end{array}$ & - & $\begin{array}{l}123.41 \\
\pm 4.84\end{array}$ & - & $\begin{array}{c}264.08 \\
\pm \\
11.07\end{array}$ \\
\hline $\begin{array}{l}\text { Butylated } \\
\text { Hydroxytoluene } \\
\text { (BHT) }\end{array}$ & - & - & - & - & - & $\begin{array}{r}139.73 \\
\pm 31.31\end{array}$ & - \\
\hline
\end{tabular}

Values are mean of five determinations \pm S.E.M of tested extract.

\section{Discussion}

Antioxidants such as phenolic compounds (tocopherols flavonoids, and phenolic acids), nitrogen compounds (alkaloids, chlorophyll derivatives, amino acids and amines), carotenoids and ascorbic acid (Larson 1988; Hall \& Cuppett 1997) compounds inhibit or delay the oxidation of other molecules by inhibiting the initiation or propagation of oxidizing chain reactions.

In this study, the metabolites shown in Table 1 were known to show biological activity as well as exhibiting physiological activity (Sofowora 1993).The result obtained in this study is also in agreement with those published by Amira \& Oloyede (2017) in which they studied the secondary metabolites present in the aqueous extract of Blighia sapida stem bark. Flavonoids are potent water-soluble antioxidants and free radical scavengers which prevent oxidative cell damage and have strong anticancer activity (Del-Rio et al. 1977; Salah et al. 1995; Okwu et al. 2006). Flavonoids also lower the risk of heart disease. Saponins are capable of neutralizing some enzymes in the intestine that can become harmful, building the immune system and promoting wound healing. Alkaloids have been documented to possess analgesic, antispasmodic and bactericidal effects. Tannins hasten the healing of wounds and inflamed mucuous membrane (Okwu et al. 2006). The presence of these phytochemicals support the medicinal use of Blighia sapida (Saidu 2012).

Zinc and selenium are the trace elements that have been found to be cofactors of antioxidant enzymes such as glutathione peroxidase and superoxide dismutase (Weydert \& Cullen 2009).

In vitro antioxidant studies revealed that hydro-ethanolic extract of Blighia sapida stem bark only showed a comparative scavenging activity when compared to the standard (i.e. ascorbic acid), by nitric oxide scavenging activity. All other parameters considered in the in vitro antioxidant studies did not show promising results when compared with the standards.

\section{Conclusion}

A major finding of the study is that hydro-ethanolic extract of Blighia sapida stem bark showed the presence of metabolites such as saponin, flavonoid, alkaloid, phenols and ascorbic acid. It was also found to contain trace elements zinc and selenium. The results also revealed that Blighia sapida stem bark hydro-ethanolic extract showed some in vitro antioxidant parameters studied, nitric oxide scavenging activity was the only one that showed a somewhat comparable $\mathrm{IC}_{50}$ to that of the standard while all others did not compare well with the chosen standards.

\section{References}

A. O. A. C. (2006): Official methods of Association of Organic and Analytical Chemists.

Abolaji, A. O., Adebayo, A. H. \& Odesanmi, O. S. (2007): Effect of ethanolic fruit extracts of Parinari polyandra (Rosaceae) on serum lipid profile and some electrolytes in pregnant rabbit. R. J. Med. Plants 1, $121-127$.

Aderinola, O.A., Farinu, G.O., Akinlade, J.A., Olayemi T.B., Ojebiyi, O.O. \& Ogunniyi, P.O. (2007):

Nutritional Potential of Blighia sapida K Konig (Ackee akkee) leaves as a dry season feed resources for West Africa dwarf goats in the derived savanna zone of Nigeria. Livestock Res. Rural Dev. 19(6), paper 78.

Amira, Philip O. \& Oloyede, Husein O.B. (2017). Phytochemical Screening and in vitro antioxidant activity of Aqueous extract of Blighia sapida stem bark. Global Journal of Medical Research (B), 17(1), 40-44.

Benzie, F.F. \& Strain, J.J. (1999). Ferric Reducing/ Antioxidant Power Assay: Direct Measure of Total 
antioxidant Activity of Biological Fluids and Modified Version for Simultaneous Measurement of Total Antioxidant Power and Ascorbic Acid Concentration. Methods in Enzymology; 299, 15-23.

Blois, M. S. (1958). Antioxidant determination by the use of a stable free radical. Nature, 181, $1199-1200$.

Boham, B. A. \& Kocipal-Abyazam, R. (1994): Flavonoids and Condensed Tannins from Leaves of Hawaiian Vaccinium vaticulatum and V. calycinium, Pacific Science 48, $458-463$.

Gardiner, M. T., William, L. A. D., T. L., Fletcher, C. K., Singh, P. D. A., Wharfe, G., Choo-kang, E., Sawh, R. N. \& Rickards, E. (1996). Extracts from Blighia sapida (Koenig) produce neutropenia and thrombocytopenia in mice. Phytother Res, 10, $689-691$.

Garrat, D. C. (1964). The quantitative analysis of drugs, volume 3, Chapman and Hall Ltd, Japan, $456-458$.

Hall, C. A. \& Cuppet, S.L. (1997). Activities of Natural antioxidants. In: Aruoma, O. I. and Cuppet, S. L. (Eds.), Antioxidant Methodology in vivo and in vitro Concepts. AOCS Press, Champaign, II, pp. 2-20.

Halliwell, B., Grooveld, M. \& Gutteridge, J. M. C. (1981). Methods of Biochemical Sciences 33, 59 - 90.

Harbone, J. B. (1973). Phytochemical Methods, London, Chapman and Hall Ltd., 49 - 199.

Holme D. \& Peck H. (1998). Analytical Biochemistry, $3^{\text {rd }}$ Edition, Prentice Hall. Addison Wesley Longman Limited.

Larson, R. A. (1988). The antioxidants of higher plants, Phytochemistry 27, 969-978.

Lin, J. M., Lin, C. C., Chen, M. F., Ujiie, T. \& Takada, A. (1995). Scavenging effects of Mallotus repandus on active oxygen species, Journal of Ethnopharmacology 46, 175-181.

Long, L. H., Evans, P. J. \& Halliwell, B. (1999). Hydrogen peroxide in human urine: implications for antioxidant defense and redox regulation, Biochem. Biophys. Res Commun. 262, 605 - 608 .

Makkar, H. P. S. (1994). Quantification of tannins. A laboratory manual international for Agricultural Research in the Dry Area (ARDA).

Obadoni, B. O. \& Ochuko, P. O. (2001). Phytochemical studies and comparative efficacy of the crude extracts of some hemostatic plants in Edo and Delta States of Nigeria, Global J. Pure Appl. Sc. 8, 203 - 208

Okwu D.U., Antai, A.B.,Udofia, K.H., Obembe A.O., Obasi K.O. \& Eteng, M.U. (2006) Vitamin C improves basal metabolic rate and lipid profile in alloxan-induced diabetes mellitus in rats, J. Biosci. 31(5), 570-575.

Oladiji, A. T., Shoremekun, K. L. \& Yakubu, M. T. (2009). Physicochemical properties of oil from the fruit of Blighia sapida and Toxicological Evaluation of the Oil-Based Diet in Wister Rats. Journal of Medicinal Food 12(5): $1127-1135$

Prieto, P., Pineda, M. \& Aguilar, M. (1999). Spectrophotometric quantitation of antioxidant capacity through the formation of a Phosphomolybdenum Complex: Specific application to the determination of vitamin E. Analytical Biochemistry 269, 337-341.

Saidu A.N., Mann A. \& Onuegbu C.D.(2012). Phytochemical Screening and Hypoglycemic Effect of Aqueous Blighia sapida Root Bark Extract on Normoglycemic Albino Rats, British Journal of Pharmaceutic Research 156, 357 - 361.

Singleton, V. L. \& Rossi, J. A., Jr. (1965). Colorimetry of total phenolics with phosphomolybdicphosphotungstic acid reagents. Am. J. Enol. Vitic. 16, 144-158

Sofowora, E. A. (!993). Medicinal Plants and Traditional Medicine in Africa. Spectrum Book Ltd. Ibadan, Nigeria, 289.

Trease, G. E. \& Evans, W. C. (2006). Pharmacognosy, $3^{\text {rd }}$ Edition, Bailliere Tidall, London, 176 - 180.

Weydert, C. J. \& Cullen, J. J. (2009). Measurement of Superoxide dismutase, catalase, and Glutathione peroxidase in cultured cells and tissue. Nat. Protoc. 5(1); $51-66$. 